\title{
A modified dinucleotide motif specifies tRNA recognition by TLR7
}

\author{
STEFFEN KAISER, ${ }^{1,3}$ KATHARINA RIMBACH, ${ }^{2,3}$ TATJANA EIGENBROD, ${ }^{2}$ ALEXANDER H. DALPKE, ${ }^{2}$ \\ and MARK HELM ${ }^{1}$ \\ ${ }^{1}$ Institute of Pharmacy and Biochemistry, Johannes Gutenberg-University Mainz, 55128 Mainz, Germany \\ ${ }^{2}$ Department of Infectious Diseases-Medical Microbiology and Hygiene, Ruprecht-Karls University Heidelberg, 69120 Heidelberg, Germany
}

\begin{abstract}
RNA can function as a pathogen-associated molecular pattern (PAMP) whose recognition by the innate immune system alerts the body to an impending microbial infection. The recognition of tRNA as either self or nonself RNA by TLR7 depends on its modification patterns. In particular, it is known that the presence of a ribose methylated guanosine at position 18, which is overrepresented in self-RNA, antagonizes an immune response. Here, we report that recognition extends to the next downstream nucleotide and the effectively recognized molecular detail is actually a methylated dinucleotide. The most efficient nucleobases combination of this motif includes two purines, while pyrimidines diminish the effect of ribose methylation. The constraints of this motif stay intact when transposed to other parts of the tRNA. The results argue against a fixed orientation of the tRNA during interaction with TLR7 and, rather, suggest a processive type of inspection.
\end{abstract}

Keywords: RNA modification; TLR7; immunostimulation; innate immunity; ribose methylation

The innate immune system guards against microbial infections by a variety of alerting pathways that rely on recognition of pathogen-associated molecular pattern (PAMP) by pattern recognition receptors (PRR). Depending on its structure and content of nucleoside modifications, DNA and RNA may serve as PAMPs that can be recognized by a large variety of PRRs (Barbalat et al. 2011; Desmet and Ishii 2012). Among those, cytosolic receptors include RIG-I-like receptors (Mafee and Valvassori 1981; Yoneyama et al. 2004), further members of the DExD/H-box helicase superfamily (Zhang et al. 2011), inflammasome activators AIM2 (Burckstummer et al. 2009; Fernandes-Alnemri et al. 2009; Hornung et al. 2009) and NLRP3 (Kanneganti et al. 2006), cyclic GMP-AMP synthase (cGAS) (Ablasser et al. 2013; Sun et al. 2013), and STING (Ishikawa et al. 2009). Furthermore, endosomal sensing of phagocytosed microbes and thereof derived nucleic acids can be mediated by Toll-like receptors (TLRs), including TLR3 (Alexopoulou et al. 2001), TLR7 (Diebold et al. 2004; Heil et al. 2004), TLR8, TLR9 (Hemmi et al. 2000), and TLR13 (Dalpke and Helm 2012; Hidmark et al. 2012; Oldenburg et al. 2012). The principles of differential recognition of self and nonself RNA are a point of outstanding interest in the field. While the number of receptors by itself

\footnotetext{
${ }^{3}$ These authors contributed equally to this work.

Corresponding authors: mhelm@uni-mainz.de,

alexander.dalpke@med.uni-heidelberg.de

Article published online ahead of print. Article and publication date are at

http://www.rnajournal.org/cgi/doi/10.1261/rna.044024.113.
}

documents the importance of this issue, details of recognition on the molecular level remain elusive. Since RNA of self and nonself origin is composed of the same four basic ribonucleotide building blocks, selective recognition and discrimination may rely on particular features of sequence (Heil et al. 2004; Vollmer et al. 2005; Diebold et al. 2006; Forsbach et al. 2008), secondary/tertiary structure (Lan et al. 2009), and processing states of the $3^{\prime}$ and $5^{\prime}$ extremities, including, e.g., $5^{\prime}$-triphosphates (Hornung et al. 2006). Whereas it is now accepted that TLR7 recognition by RNA requires certain sequence orders (Hornung et al. 2005), an exact stimulatory motif is still ill-defined. Finally, a more recently discovered discriminatory property is post-transcriptional modification of nucleic acids. Several examples pertaining to the latter have demonstrated both the capability for effective inspection and intricate interaction by the innate immune system, as well as the importance of a deeper understanding of its molecular details (Krieg et al. 1995; Kariko et al. 2005; Robbins et al. 2007; Dalpke and Helm 2012).

Recently, several groups, including us, reported on the recognition of tRNA by the endosomal TLR7 (Gehrig et al. 2012; Jockel et al. 2012). In these studies, naturally occurring nucleoside modifications within tRNA have clearly been identified 
as structural anti-determinants for innate immune recognition. Immune activation via TLR7 can be triggered by any unmodified tRNA, as well as by many bacterial tRNAs that contain few modifications in comparison to the eukaryotic tRNA counterparts. The relative abundance of modifications in eukaryotic tRNA appears to be a key feature (Cantara et al. 2011; Machnicka et al. 2013), but the picture is rather incomplete, since many eukaryotic modifications also occur in bacteria. A case in point is the Gm18 modification, which was shown to act as an antagonist in TLR7-mediated signaling, even when present in bacterial tRNA. Gm denotes a ribose methylation on the $2^{\prime}$-hydroxylfunction of a guanosine residue in the structural core of the typical L-shaped tRNA. Its primary function is likely a structural stabilization of this region (Motorin and Helm 2010; Ochi et al. 2010; Ishida et al. 2011), whereas a function in immune recognition is assumed to have evolved as a secondary feature. Whereas this modification is found in many archaea, bacteria, and eukaryotes, it occurs only in a subset of five tRNA species from Escherichia coli (Jühling et al. 2009).

Upon substitution of Gm and its downstream next neighbor nucleoside, we observed highly interesting effects, which persist even when the modification is transplanted into parts of $E$. coli tRNA ${ }^{\mathrm{Tyr}}$ where it does not naturally occur. We constructed a number of modivariants (Madore et al. 1999) by splint ligation of synthetic oligoribonucleotides and tested the corresponding TLR7-mediated response. Therefore, peripheral blood mononuclear cells (PBMCs) from at least five human donors were stimulated with DOTAP encapsulated tRNA preparations. An ELISA assay (Gehrig et al. 2012) was used measuring interferon $\alpha$ secretion (INF- $\alpha$ ) by plasmacytoid dendritic cells ( $\mathrm{pDC}$ ) to determine TLR7 activity.

Mutations at position 18, surprisingly, revealed that the nature of the nucleobases is less important (Fig. 1A); all variations of nucleobases in combination with a methylated ribose and a downstream purine lead to efficient and highly significant silencing.

Cytidine 18 is an exception to some degree in that it does lead to silencing but less efficiently and with strong variation among the five donors. We previously reported similar but less pronounced effects of ribose-methylated cytidine in synthetic siRNA, where permethylated ribose modification of adenosine and uridine, but not of cytidine, decreased immunostimulation (Eberle et al. 2008). We conclude that the ribose methylation itself is recognized along with structural features other than the nucleobase \#18. This unexpected finding prompted us to investigate permutations of the nucleoside at position 19, i.e., directly downstream from the methylated ribose. These experiments revealed that ribose methylation at position 18 by itself is not sufficient but highly efficient in combination with a downstream purine (Fig. 1B). This combination corresponds to the native occurrences of Gm18 in tRNA (Jühling et al. 2009), such as Gm18-G19. The presence of pyrimidines at the +1 position is clearly detrimental to the immunosilencing effect. The effect is milder for uridine (GmU19) but quantitative for cytidine (GmC19).

Together, these results imply a functional $[\mathrm{DmR}]$ motif (D $=$ all but $\mathrm{C} ; \mathrm{R}=$ purine) featuring a methylated ribose in a dinucleotide unit with a $3^{\prime}$ purine. To verify this hypothesis, we moved the ribose methylation downstream by $1 \mathrm{nt}$ unit within the native tRNA sequence. The resulting construct is identical in sequence and molecular weight to the immunosilent parent Gm18 tRNA and differs only in the position of the ribose methylation by $\sim 5 \AA$. The direct comparison in Figure 1C shows that the silencing by ribose methylation is negatively affected in this construct, again with noticeable donor variation. Strikingly, as also shown in Figure 1C, it can be functionally recovered by reconstituting the intact methylated dinucleotide signal [DmR] via insertion of a guanosine $3^{\prime}$ to the ribose methylation at position 20 .

The above results correspond to a transposition of the [DmR] motif by $1 \mathrm{nt}$ toward the $3^{\prime}$, and the fact that it remains functionally intact upon transposition triggers the question if it can be moved to a completely different structural context within the same tRNA scaffold. Hence, the $[\mathrm{DmR}]$ motif was transplanted into two other loop regions of the tRNA: position 34, where it naturally occurs in eukaryotic tRNAs such as tRNA ${ }^{\text {Phe }}$ (Jühling et al. 2009), and position 57, where it has not been detected so far. Figure 1, D and $\mathrm{E}$ shows that the results of permutation studies of methylated nucleosides at these positions strongly resemble those conducted at position 18 , with only minor variations.

The common denominators of permutation studies at all three locations, i.e., the D-loop, the anticodon loop, and the T-loop, are as follows: (1) Purine bases on $3^{\prime}$ side of the methylated ribose produce maximum silencing efficiency; (2) pyrimidines are generally detrimental to silencing; (3) with cytidine more so than uridine; and (4) donor variation is in evidence, which is especially noticeable for dinucleotides containing pyrimidines.

The observed ranking of stimulation efficiency stays intact at different concentrations, as illustrated in Figure 2, where a titration with increasing amounts of the four principle modivariants Gm18, Am18, Um18, and $\mathrm{Cm} 18$ is normalized to the effect of the unmodified in vitro transcript. Furthermore, it was verified that the nonstimulatory effect is also an inhibitory effect, by cotransfection of a selection of modivariants with stimulating in vitro transcript (Fig. 3). Note the correlation of immunosilent modivariants (Fig. 1) with immunosuppressing modivariants in Figure 3. Indeed, the relative suppression of IFN- $\alpha$ secretion by modivariants adhering to the above mentioned common denominators is faithfully reproduced in the assays shown in Figure 3, which now represent actual immunosuppression experiments. Rather than just being immunosilent, i.e., not recognized by TLR7, the modivariants antagonize the immunoactivating properties of the unmodified in vitro transcript.

We conclude that we have identified a dinucleotide motif which includes a post-transcriptional methylation as the 
A

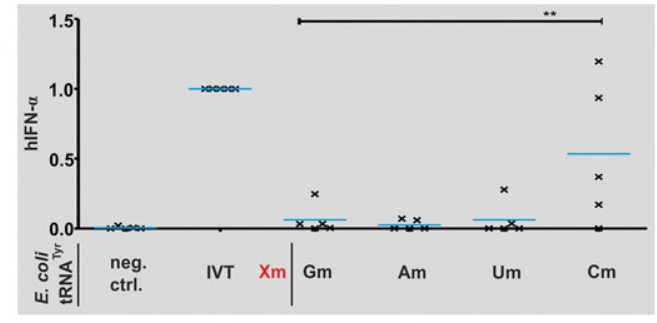

B

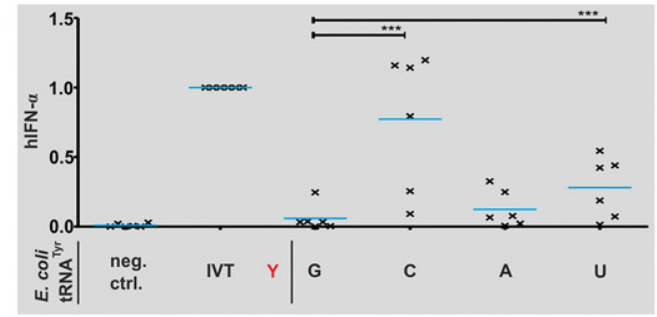

C

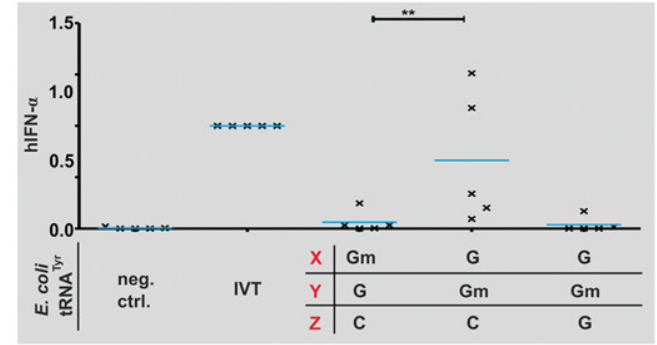

D

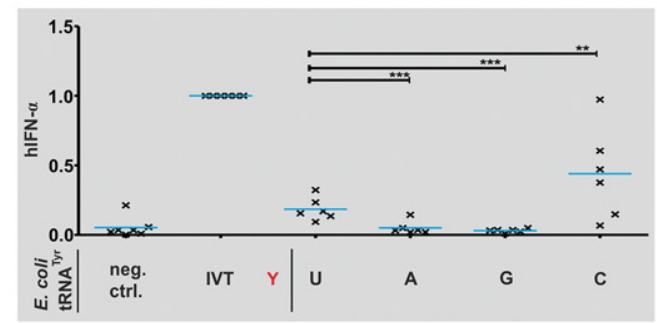

E

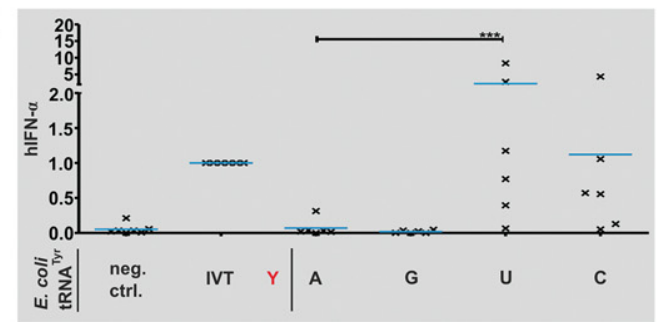

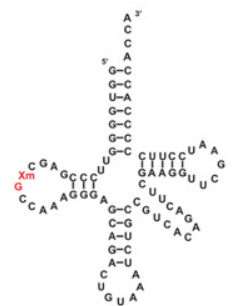
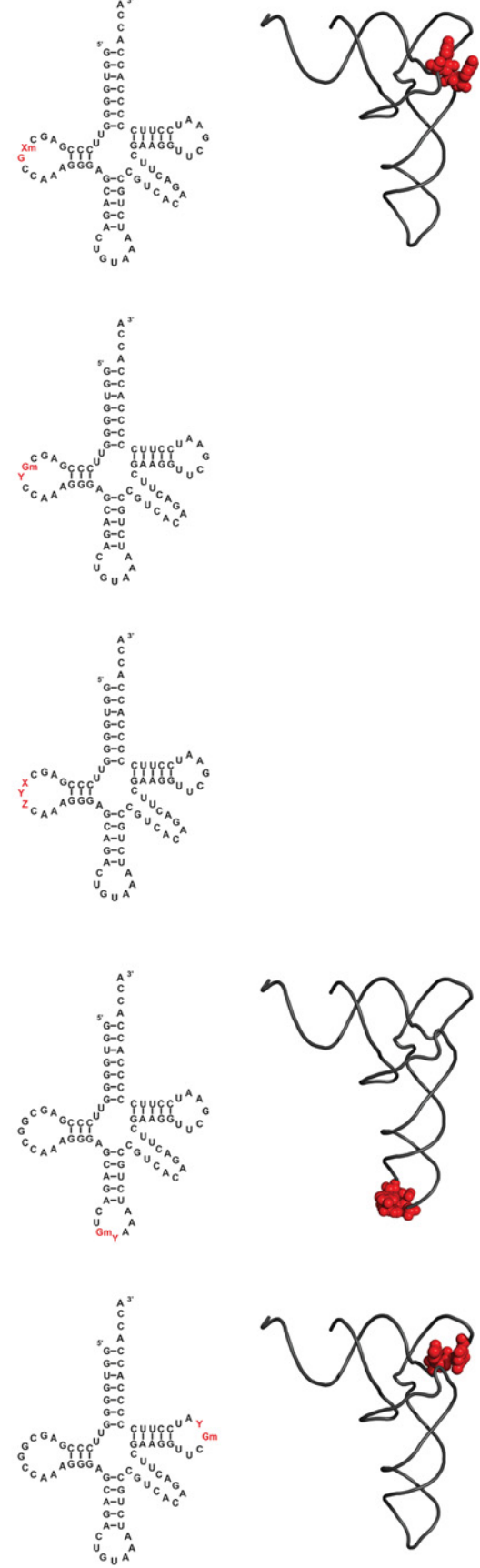

FIGURE 1. Effect and localization of the DmR dinucleotides motif responsible for TLR7 silencing by tRNA. PBMCs of five to six different donors were activated by transfection with $500 \mathrm{ng} / \mathrm{mL}$ tRNA (if not indicated otherwise) encapsulated in DOTAP ( $N$-[1-(2, 3-dioleoyloxy)propyl]- $N, N, N$ trimethylammonium methylsulfate) as described in detail in Gehrig et al. (2012). Interferon a production from plasmacytoid dendritic cells was measured by ELISA and was normalized to the unmodified tRNA transcript (IVT, in vitro transcript). Each dot in the figure represents one donor. To test for significance, Student's $t$-test was performed. $\left(^{* *}\right) P<0.01,\left({ }^{* * *}\right) P<0.001$. (A) Effect of permutation of nucleotide Xm18. (B) Permutation of Y19. (C) Transplantation of the motif by $1 \mathrm{nt}$ downstream. $(D)$ Transplantation of the motif to the anticodon loop and permutation. $(E)$ Transplantation of the motif to the T-loop and permutation.

decisive structural element for an inhibition of TLR7-meditated immune activation. This bears some resemblance to the reported effects of the presence of 5-methylcytidine in CpG motifs on recognition of DNA by TLR9, which is also an endosomal nucleic acid-dependent PRR (Hemmi et al.
2000). While the extent of further similarities is unclear, the structure of tRNA used in our case helps to further our understanding of the actual recognition event somewhat. When comparing the X-ray structure (Liu et al. 2008) of a 40-mer double-stranded RNA complexed to TLR3, a tRNA molecule 
spans a distance long enough to sustain a receptor dimerization as observed with TLR3. However, structures of TLR8 alone and in complex with a small molecule effector strongly show that recognition, dimerization, and downstream signaling can, in principle, be affected by molecules that do not span the entire width of the receptor (Tanji et al. 2013). In keeping with this, TLR7 signaling is actively antagonized by the presence of our [DmR] motif at several positions within the tRNA structure, implying several different functional orientations of the tRNA during TRL7 recognition. This, in turn, means that any such interaction cannot be of completely static nature. In this respect, our data point to a processive type of RNA inspection, where TLR7 scans different regions of the tRNA molecule until stuck at the dinucleotide motif.

\section{MATERIALS AND METHODS}

\section{Synthesis of modivariants}

Splinted ligation was performed by annealing three synthetic fragments of RNA (IBA Göttingen; 5' fragment: GGUGGGGUUCCC GAGCGGCCAAAG; middle fragment: GGAGCAGACUGUAAA UCUGCCGUCACAG; 3’ fragment: ACUUCGAAGGUUCGAAU CCUUCCCCCACCACCA), corresponding in sequence to unmodified E. coli $\mathrm{tRNA}^{\mathrm{Tyr}}$ or its modivariants/mutants onto a reverse complementary oligodeoxynucleotide (IBA Göttingen; TGGTGGT GGGGGAAGGATTCGAACCTTCGAAGTCTGTGACGGCAGATTT ACAGTCTGCTCCCTTTGGCCGCTCGGGAACCCCACC). Appropriate fragments $(4 \mathrm{nmol})$ were $5^{\prime}$-phosphorylated by incubating in $\mathrm{KL}$ buffer (50 mM Tris- $\mathrm{HCl}$ [pH 7.4], $10 \mathrm{mM} \mathrm{MgCl}_{2}$ ) supplemented with $5 \mathrm{mM}$ ATP, $5 \mathrm{mM} \mathrm{DTT}$, and 0.75 units/ $\mu \mathrm{L}$ T4 polynucleotide kinase (PNK, Fermentas) in a final volume of $150 \mu \mathrm{L}$ in the thermomixer at $37^{\circ} \mathrm{C}$ for $1 \mathrm{~h}$. To the phosphorylation reaction mixture, an equimolar amount of the $5^{\prime}$ fragment and the DNA splint were added, as well as KL buffer, ATP ( $5 \mathrm{mM})$, and DTT ( $5 \mathrm{mM}$ ), leading to a final volume of $500 \mu \mathrm{L}$ and an $8 \mu \mathrm{M}$ concentration of each fragment. The RNA fragments were hybridized to the DNA splint by heating to $75^{\circ} \mathrm{C}$ in the thermomixer for $4 \mathrm{~min}$ and letting the reaction mixture cool down to room temperature for $15 \mathrm{~min}$.

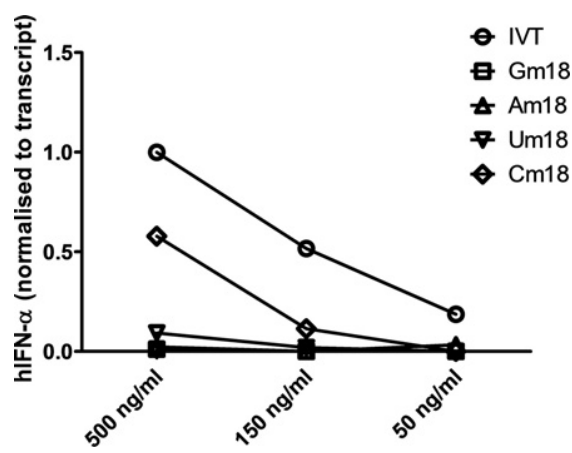

FIGURE 2. Titration of different stimulatory tRNA variants. PBMCs were transfected with different concentrations $(500 \mathrm{ng} / \mathrm{mL}, 150 \mathrm{ng} /$ $\mathrm{mL}, 50 \mathrm{ng} / \mathrm{mL}$ ) of the indicated tRNA modivariants. IFN- $\alpha$ production was measured by ELISA and normalized to unmodified in vitro transcript (IVT, $500 \mathrm{ng} / \mathrm{mL}$ ).

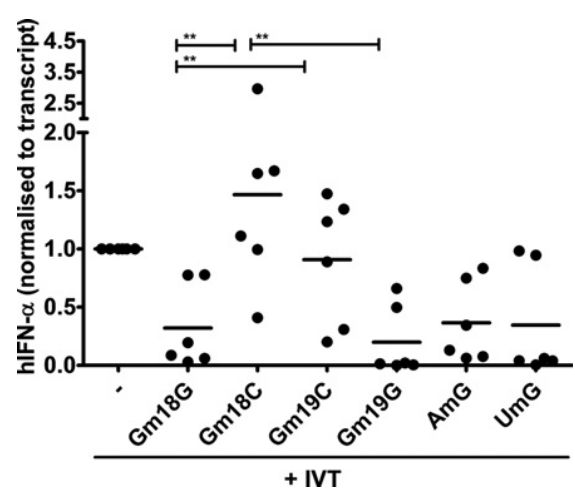

FIGURE 3. Immunosuppressing activity of selected RNA modivariants. Five hundred nanograms per milliliter of in-vitro transcript (IVT) were cotransfected with or without ("-" label) $500 \mathrm{ng} / \mathrm{mL}$ tRNA modivariant to test for suppressive activity. IFN- $\alpha$ production was measured by ELISA and normalized to IVT alone (“-”). Each dot in the figure represents one donor. To test for significance, Student's $t$-test was performed. (**) $P<0.01$.

Then, T4 DNA ligase (1.5 units/ $\mu \mathrm{L}$; Fermentas) and T4 RNA ligase $2(22 \mathrm{ng} / \mu \mathrm{L})$ were added, and the ligation was performed in the thermomixer at $16^{\circ} \mathrm{C}$ overnight. Template DNA was removed by addition of 1.5 units/ $\mu \mathrm{L}$ DNase I (Fermentas), followed by $1 \mathrm{~h}$ of incubation at $37^{\circ} \mathrm{C}$. The tRNAs were purified from ligation mixtures by denaturing PAGE, excised and eluted from the gel, and precipitated with ethanol. Concentrations were calculated from absorption at $254 \mathrm{~nm}$, as determined on a Nanodrop ND-1000 spectrometer after resuspension in water.

\section{Stimulation of peripheral blood mononuclear cells with tRNAs}

Human PBMCs were isolated from heparinized blood of healthy donors upon informed consent by standard Ficoll-Hypaque densitygradient centrifugation (Ficoll $1.078 \mathrm{~g} / \mathrm{mL}$ ) (Eberle et al. 2008). PBMCs were resuspended in complete medium prepared of RPMI 1640 supplemented with heat-inactivated $\left(1 \mathrm{~h}, 56^{\circ} \mathrm{C}\right) 10 \%$ FCS. Five hundred nanograms of tRNA sample was diluted in a volume of $50 \mu \mathrm{L}$. The RNA was encapsulated with $2 \mu \mathrm{L}$ of $1 \mathrm{mg} / \mathrm{mL}$ DOTAP (N-[1-(2, 3-dioleoyloxy)propyl]-N, N, N-trimethylammonium methylsulfate) (Roth) by mixing with serum-free medium and incubation for $10 \mathrm{~min}$. Cells were plated on top of the transfection mixture at $4 \times 10^{5}$ cells/well in a 96-well flat bottom plate. PBMCs were incubated in a humidified $5 \% \mathrm{CO}_{2}$ atmosphere at $37^{\circ} \mathrm{C}$ for $16 \mathrm{~h}$. As an internal positive control, PBMCs were stimulated with the TLR9specific stimulus CpG2216 (1 $\mu \mathrm{M})$ and the TLR7/8-agonist R848 (1 $\mu \mathrm{g} / \mathrm{mL}$ ) (InvivoGen). Cell-free supernatant was analyzed for secretion of IFN- $\alpha$ using a sandwich ELISA (Bender MedSystems).

\section{ACKNOWLEDGMENTS}

We acknowledge funding by the Deutsche Forschungsgemeinschaft (DFG) to M.H. (HE 3397/9) and A.H.D. (DA 592/5).

Received December 18, 2013; accepted June 6, 2014. 


\section{REFERENCES}

Ablasser A, Goldeck M, Cavlar T, Deimling T, Witte G, Rohl I, Hopfner KP, Ludwig J, Hornung V. 2013. cGAS produces a 2'-5'linked cyclic dinucleotide second messenger that activates STING. Nature 498: 380-384.

Alexopoulou L, Holt AC, Medzhitov R, Flavell RA. 2001. Recognition of double-stranded RNA and activation of NF- $\kappa$ B by Toll-like receptor 3. Nature 413: 732-738.

Barbalat R, Ewald SE, Mouchess ML, Barton GM. 2011. Nucleic acid recognition by the innate immune system. Annu Rev Immunol 29: 185-214.

Burckstummer T, Baumann C, Bluml S, Dixit E, Durnberger G, Jahn H, Planyavsky M, Bilban M, Colinge J, Bennett KL, et al. 2009. An orthogonal proteomic-genomic screen identifies AIM2 as a cytoplasmic DNA sensor for the inflammasome. Nat Immunol 10: 266-272.

Cantara WA, Crain PF, Rozenski J, McCloskey JA, Harris KA, Zhang X, Vendeix FA, Fabris D, Agris PF. 2011. The RNA Modification Database, RNAMDB: 2011 update. Nucleic Acids Res 39(Database issue): D195-D201.

Dalpke A, Helm M. 2012. RNA mediated Toll-like receptor stimulation in health and disease. RNA Biol 9: 828-842.

Desmet CJ, Ishii KJ. 2012. Nucleic acid sensing at the interface between innate and adaptive immunity in vaccination. Nat Rev Immunol 12: 479-491.

Diebold SS, Kaisho T, Hemmi H, Akira S, Reis e Sousa C. 2004. Innate antiviral responses by means of TLR7-mediated recognition of single-stranded RNA. Science 303: 1529-1531.

Diebold SS, Massacrier C, Akira S, Paturel C, Morel Y, Reis e Sousa C. 2006. Nucleic acid agonists for Toll-like receptor 7 are defined by the presence of uridine ribonucleotides. Eur J Immunol 36: 3256-3267.

Eberle F, Giessler K, Deck C, Heeg K, Peter M, Richert C, Dalpke AH. 2008. Modifications in small interfering RNA that separate immunostimulation from RNA interference. J Immunol 180: 3229-3237.

Fernandes-Alnemri T, Yu JW, Datta P, Wu J, Alnemri ES. 2009. AIM2 activates the inflammasome and cell death in response to cytoplasmic DNA. Nature 458: 509-513.

Forsbach A, Nemorin JG, Montino C, Muller C, Samulowitz U, Vicari AP, Jurk M, Mutwiri GK, Krieg AM, Lipford GB, et al. 2008. Identification of RNA sequence motifs stimulating sequence-specific TLR8-dependent immune responses. J Immunol 180: 3729-3738.

Gehrig S, Eberle ME, Botschen F, Rimbach K, Eberle F, Eigenbrod T, Kaiser S, Holmes WM, Erdmann VA, Sprinzl M, et al. 2012. Identification of modifications in microbial, native tRNA that suppress immunostimulatory activity. J Exp Med 209: 225-233.

Heil F, Hemmi H, Hochrein H, Ampenberger F, Kirschning C, Akira S, Lipford G, Wagner H, Bauer S. 2004. Species-specific recognition of single-stranded RNA via toll-like receptor 7 and 8. Science 303: $1526-1529$.

Hemmi $\mathrm{H}$, Takeuchi O, Kawai $\mathrm{T}$, Kaisho $\mathrm{T}$, Sato $\mathrm{S}$, Sanjo $\mathrm{H}$ Matsumoto M, Hoshino K, Wagner H, Takeda K, et al. 2000. A Toll-like receptor recognizes bacterial DNA. Nature 408: 740-745.

Hidmark A, von Saint Paul A, Dalpke AH. 2012. Cutting edge: TLR13 is a receptor for bacterial RNA. J Immunol 189: 2717-2721.

Hornung V, Guenthner-Biller M, Bourquin C, Ablasser A, Schlee M, Uematsu S, Noronha A, Manoharan M, Akira S, de Fougerolles A, et al. 2005. Sequence-specific potent induction of IFN- $\alpha$ by short interfering RNA in plasmacytoid dendritic cells through TLR7. Nat Med 11: 263-270.

Hornung V, Ellegast J, Kim S, Brzozka K, Jung A, Kato H, Poeck H, Akira S, Conzelmann KK, Schlee M, et al. 2006. 5'-Triphosphate RNA is the ligand for RIG-I. Science 314: 994-997.

Hornung V, Ablasser A, Charrel-Dennis M, Bauernfeind F, Horvath G, Caffrey DR, Latz E, Fitzgerald KA. 2009. AIM2 recognizes cytosolic dsDNA and forms a caspase-1-activating inflammasome with ASC. Nature 458: 514-518.

Ishida K, Kunibayashi T, Tomikawa C, Ochi A, Kanai T, Hirata A, Iwashita C, Hori H. 2011. Pseudouridine at position 55 in tRNA controls the contents of other modified nucleotides for low-temperature adaptation in the extreme-thermophilic eubacterium Thermus thermophilus. Nucleic Acids Res 39: 2304-2318.
Ishikawa H, Ma Z, Barber GN. 2009. STING regulates intracellular DNAmediated, type I interferon-dependent innate immunity. Nature 461: 788-792.

Jockel S, Nees G, Sommer R, Zhao Y, Cherkasov D, Hori H, Ehm G, Schnare M, Nain M, Kaufmann A, et al. 2012. The 2'-O-methylation status of a single guanosine controls transfer RNA-mediated Tolllike receptor 7 activation or inhibition. J Exp Med 209: 235-241.

Jühling F, Mörl M, Hartmann RK, Sprinzl M, Stadler PF, Pütz J. 2009. tRNAdb 2009: Compilation of tRNA sequences and tRNA genes. Nucleic Acids Res 37(Database issue): D159-D162.

Kanneganti TD, Ozoren N, Body-Malapel M, Amer A, Park JH, Franchi L, Whitfield J, Barchet W, Colonna M, Vandenabeele P, et al. 2006. Bacterial RNA and small antiviral compounds activate caspase-1 through cryopyrin/Nalp3. Nature 440: 233-236.

Kariko K, Buckstein M, Ni H, Weissman D. 2005. Suppression of RNA recognition by Toll-like receptors: the impact of nucleoside modification and the evolutionary origin of RNA. Immunity 23: 165-175.

Krieg AM, Yi AK, Matson S, Waldschmidt TJ, Bishop GA, Teasdale R, Koretzky GA, Klinman DM. 1995. CpG motifs in bacterial DNA trigger direct B-cell activation. Nature 374: 546-549.

Lan T, Putta MR, Wang D, Dai M, Yu D, Kandimalla ER, Agrawal S. 2009. Synthetic oligoribonucleotides-containing secondary structures act as agonists of Toll-like receptors 7 and 8. Biochem Biophys Res Commun 386: 443-448.

Liu L, Botos I, Wang Y, Leonard JN, Shiloach J, Segal DM, Davies DR. 2008. Structural basis of toll-like receptor 3 signaling with doublestranded RNA. Science 320: 379-381.

Machnicka MA, Milanowska K, Osman Oglou O, Purta E, Kurkowska M, Olchowik A, Januszewski W, Kalinowski S, DuninHorkawicz S, Rother KM, et al. 2013. MODOMICS: A database of RNA modification pathways-2013 update. Nucleic Acids Res 41 (Database issue): D262-D267.

Madore E, Florentz C, Giegé R, Sekine S, Yokoyama S, Lapointe J. 1999. Effect of modified nucleotides on Escherichia coli tRNA $^{\text {Glu }}$ structure and on its aminoacylation by glutamyl-tRNA synthetase. Predominant and distinct roles of the mnm5 and s2 modifications of U34. Eur J Biochem 266: 1128-1135.

Mafee MF, Valvassori GE. 1981. Radiology of the craniofacial anomalies. Otolaryngol Clin North Am 14: 939-988.

Motorin Y, Helm M. 2010. tRNA stabilization by modified nucleotides. Biochemistry 49: 4934-4944.

Ochi A, Makabe K, Kuwajima K, Hori H. 2010. Flexible recognition of the tRNA G18 methylation target site by TrmH methyltransferase through first binding and induced fit processes. J Biol Chem 285: 9018-9029.

Oldenburg M, Kruger A, Ferstl R, Kaufmann A, Nees G, Sigmund A, Bathke B, Lauterbach H, Suter M, Dreher S, et al. 2012. TLR13 recognizes bacterial $23 \mathrm{~S}$ rRNA devoid of erythromycin resistance-forming modification. Science 337: 1111-1115.

Robbins M, Judge A, Liang L, McClintock K, Yaworski E, MacLachlan I. 2007. 2'-O-methyl-modified RNAs act as TLR7 antagonists. Mol Ther 15: 1663-1669.

Sun L, Wu J, Du F, Chen X, Chen ZJ. 2013. Cyclic GMP-AMP synthase is a cytosolic DNA sensor that activates the type I interferon pathway. Science 339: 786-791.

Tanji H, Ohto U, Shibata T, Miyake K, Shimizu T. 2013. Structural reorganization of the Toll-like receptor 8 dimer induced by agonistic ligands. Science 339: 1426-1429.

Vollmer J, Tluk S, Schmitz C, Hamm S, Jurk M, Forsbach A, Akira S, Kelly KM, Reeves WH, Bauer S, et al. 2005. Immune stimulation mediated by autoantigen binding sites within small nuclear RNAs involves Toll-like receptors 7 and 8. J Exp Med 202: 1575-1585.

Yoneyama M, Kikuchi M, Natsukawa T, Shinobu N, Imaizumi T, Miyagishi M, Taira K, Akira S, Fujita T. 2004. The RNA helicase RIG-I has an essential function in double-stranded RNA-induced innate antiviral responses. Nat Immunol 5: 730-737.

Zhang Z, Kim T, Bao M, Facchinetti V, Jung SY, Ghaffari AA, Qin J, Cheng G, Liu YJ. 2011. DDX1, DDX21, and DHX36 helicases form a complex with the adaptor molecule TRIF to sense dsRNA in dendritic cells. Immunity 34: 866-878. 

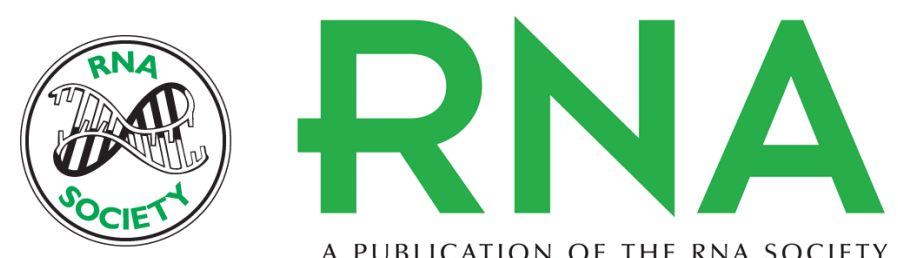

A PUBLICATION OF THE RNA SOCIETY

\title{
A modified dinucleotide motif specifies tRNA recognition by TLR7
}

\author{
Steffen Kaiser, Katharina Rimbach, Tatjana Eigenbrod, et al.
}

RNA 2014 20: 1351-1355 originally published online July 22, 2014

Access the most recent version at doi:10.1261/rna.044024.113

\section{References This article cites 40 articles, 14 of which can be accessed free at: http://rnajournal.cshlp.org/content/20/9/1351.full.html\#ref-list-1}

Creative This article is distributed exclusively by the RNA Society for the first 12 months after the Commons full-issue publication date (see http://rnajournal.cshlp.org/site/misc/terms.xhtml). After 12 License months, it is available under a Creative Commons License (Attribution-NonCommercial 4.0 International), as described at http://creativecommons.org/licenses/by-nc/4.0/.

Email Alerting Receive free email alerts when new articles cite this article - sign up in the box at the Service top right corner of the article or click here. 